\title{
New perspectives on Byzantine Spain: The Discriptio Hispaniae
}

Oriol Olesti Vila, Ricard Andreu Expósito (Universitat Autònoma de Barcelona) and Jamie Wood (University of Lincoln)

\begin{abstract}
The Discriptio Hispaniae is a passage from the Geometry of Gisemundus, also entitled Ars Gromatica Gisemundi (AGG), a medieval treatise of agrimensura written by an unknown author, probably a monk known as Gisemundus who had some agrimensorial experience. The work was compiled around 800 A.D. by collecting passages of a range of sizes, from just a few words to several pages, extracted from ancient and medieval sources. Although modern research into Roman agrimensorial texts has admitted the importance of the AGG, its corrupt condition has not invited sustained analysis. The passage now known as the Discriptio Hispaniae, a short section from chapter three of the second book of the AGG entitled III De segregatione provinciarum ab Augustalibus terminis, is particularly interesting for the information that it provides concerning the territorial division of Hispania in late antiquity. This article presents an edition and English translation of the Discriptio Hispaniae and argues that the most likely point of origin for the Discriptio Hispaniae is during the Byzantine occupation of parts of southern Spain during the second half of the sixth century and the first quarter of the seventh century. We suggest that the Discriptio Hispaniae was preserved because the Byzantine autorities were keen to keep on record information about the borders of the province of Carthaginensis, perhaps the main theme in the text.
\end{abstract}

\section{Keywords}

Byzantine, Spain, Iberian Peninsula, Justinian, Manuscripts

\section{Introduction}

The Discriptio Hispaniae is a passage from the Geometry of Gisemundus, also entitled Ars Gromatica Gisemundi $(A G G)$, a medieval treatise of agrimensura written by an unknown author, probably a monk known as Gisemundus who had some agrimensorial experience. The work was compiled around 800 A.D. by collecting passages of a range of sizes, from just a few words to several pages, extracted from ancient and medieval sources. Gisemundus had at his disposal a range of relevant resources, including materials from the Corpus Agrimensorum Romanorum (CAR), a copy of a Pseudo-Boethian geometry (liber I or Demonstratio artis Geometricae) and Orosius' Historia adversus Paganos. ${ }^{1}$ The sources are well known to us, but we can presume that the author also used others which are now lost. The $A G G$ is an exceptional source not only for the knowledge of ancient land surveying texts that it contains but also for understanding their transmission into and beyond the early medieval period. Although modern research into Roman agrimensorial texts has admitted the importance of the $A G G$, its corrupt condition has not invited sustained analysis.

The $A G G$ was first preserved in a now lost manuscript written in Visigothic script in northwest Spain². Most of the text of the $A G G$ was incorporated, via a damaged copy of the original, into a miscellaneous manuscript dated to the second half of the ninth century

\footnotetext{
1 Thulin (1911); Toneatto (1982), 195.

2 Andreu (2015), 14-26, provides an overview of the evidence for the work's Visigothic origin, including: confusion between letters (especially $a$ and $u$ ), abbreviations (per/pro and the number 1000), and Latin orthographic features. See also: Andreu (2011).
} 
(Barcelona, ACA, Ms. Ripoll 106; 76r-89r,13). ${ }^{3}$ The Catalan scribe had some difficulty deciphering the text due to the Visigothic characters, some abbreviation signs and the treatise's obscure subject matter. His copy, made in Carolingian script, was very corrupt and this accounts for the fact that this text has received minimal scholarly attention until recently. More positively, because the text was so difficult, the copyist seems to have been reluctant to make conjectures or introduce glossae into the text. There is another fragmentary copy of the $A G G$ in Paris, BnF, Ms. lat. 8812 (67r-76v), which does not contain the Discriptio Hispaniae.

Rudolf Beer (1907) discovered the $A G G$ and, although Carl Thulin studied its content (1911), it was not until 1931 that Millàs Vallicrosa offered a first partial edition of the text. He stressed the importance of Ripoll 106 for the history of science in medieval Catalonia and hence did not produce a critical edition. More recently, Lucio Toneatto's thorough study and partial edition of the $A G G$ has come to the attention of scholars working on ancient land surveying. ${ }^{4}$ Toneatto identified the origin of all excerpta with known sources and examined passages that he considered most interesting, usually those from an unidentified source or those that varied from the CAR tradition. Perhaps surprisingly, historians have not picked up on his edition of the Discriptio Hispaniae despite the potentially interesting data it contains for Roman and post-Roman Spain.

Since 2011, a series of studies by Ricard Andreu has led to the publication of the first complete critical edition of the text and translations into Catalan and Castilian. ${ }^{5}$ Andreu's edition differs from that of Toneatto in several respects, primarily: a different reconstruction of the sequence of texts (which has no effect on the text of the Discriptio Hispaniae); establishing the Visigothic origin of the source, which helps to explain many of the transmission errors and, when taken into account, facilitates the reconstruction of a number of passages within the text; establishing connections with recent archaeological work. It is now clear that, despite its corrupt condition, that the $A G G$ can provide new insights into Roman agrimensorial writings and their early medieval transmission histories. For example, the $A G G$ contains passages with no known sources, such as the Discriptio Hispaniae and some Casae Litterarum. In addition, the overall design and execution of the treatise, including its division in two books and the inclusion of an index for the second book, are elements that demonstrates Gisemundus' agency in putting together the text: he was not merely a copyist or a compiler, but engaged thoughtfully and creatively with his sources to generate a new work. Gisemundus' address to his readers at the beginning and at the end of the second book underlines his active role in putting together the text:

complexus sum, me iudico, tibi contingat optamus, breuiter insinuamus ut doceas, ego

Gisemundus docentibus loquor, nos uero in primis simus corde et mente prope deum ${ }^{6}$

Gisemundus clearly possessed some knowledge of agrimensorial texts and perhaps had some experience of using them in practice.

\section{The Discriptio Hispaniae}

The passage now known as the Discriptio Hispaniae, a short section from chapter three of the second book of the $A G G$ entitled III De segregatione provinciarum ab Augustalibus

\footnotetext{
${ }^{3}$ Munk Olsen (1982-1989).

${ }^{4}$ Toneatto (1982) and (1994-1995); see also Campbell (2000) and Peyras (2005).

${ }^{5}$ Andreu (2011), (2013) and (2015).

${ }^{6}$ Andreu (2015), 116 and $144 ; Z 81 \mathrm{r}$ and $80 \mathrm{v} ; \mathrm{n}$. b. the order of the text is inverted in the manuscript, Andreu (2015) II.5, 32-43.
} 
terminis, is particularly interesting for the information that it provides concerning the territorial division of Hispania in late antiquity. ${ }^{7}$ It is positioned between chapter two, dedicated to the division of the orbis terrae, and chapter four, which refers to ius territorii. It has been named Discriptio Hispaniae despite the fact that it is not really a geographical 'description', but rather distributes Spain's land into provinces according to the principles of land surveying. It begins with extracts from Orosius, which have been rewritten by Gisemundus. ${ }^{8}$ The author used one or more unknown land surveying sources to construct the Discriptio Hispaniae. Internal evidence dates these sources to late antiquity. The following section reproduces the text as it is published in Andreu's 2015 edition, accompanied by the critical apparatus and the first English translation of the text.

${ }^{7}$ Andreu (2015), 122, 8-126, 3; Z, f. 81v 32-82r 24.

8 Orosius, Historia adversus Paganos I.2, Zangemeister, ed. (1889), 69-72. 


\section{LATIN TEXT: Discriptio Hispaniae}

$<\mathrm{Hi}>$ spania uniuersa terrarum situ trigonia est et circumsaepta a mare Oceano in duabus partibus constat, id est, a septentrione et meridie. uero a parte orientis mare Tyrrheno terminatur. huius angulus prior in Narbonensium finibus desinit. secundus angulus circium intendit ubi Brigantia ciuitas sita est et altissimum farum. tertius angulus eius est in Gadi $<$ bu $>$ s ubi est columna Herculis. et sunt in ea trigonea iterum duae $<\mathrm{Hi}>$ spaniae: citerior et ulterior.

Citeriore $<\mathrm{m}><\mathrm{Hi}>$ spania $<\mathrm{m}>$ Carthago determinat. hic Iulius Caesar Franci[s]cus Gepidicus

10 Africanus et $\mathrm{E}<\mathrm{u}>$ ropensis castellorum oppidorumque $<$ quae $>$ ad metropolitana[m] pertinebant iura terminos constituit $\mathrm{e}<\mathrm{t}>$ [f]flumina quae mergebant in Oceano demetiuit.

$\mathrm{A}[\mathrm{u}]$ tque terminus Palentinus aut Carthaginiensis aut Celtiberus super superiore prouincia quae Galli $<\mathrm{ci}>$ a nuncupatur, hos terminos constructos reliquimus. Iber uero fluuius, qui $<\mathrm{I}>$ beriam certam diuidit prouincia $<\mathrm{m}>$, currit milia CCCXXVIIII quae Numantia, Vardulia, Cantabria, ad

15 Carthaginiense $<\mathrm{m}>$ metropolitanam pertine $<\mathrm{n}>\mathrm{t}$. nam omnia trifinia de Carthagine processerunt. uenit usque ad ter $<$ mi $>$ num Baetis ubi Corduba sita est $<$ et $>$ Carthago nuncupatur. inde surgit Baetica quae ad Gaditanum stagnum pertinet. inde $\mathrm{A}<\mathrm{u}>$ gusta $\mathrm{E}[\mathrm{t}]$ merita quae et Lusitania nuncupatur. currunt termini ipsius usque ad urbem metropolitanam Bracara $<\mathrm{m}>$, cui Gallicia pertinet. ipsius sunt termini et procedunt calles calciatas in miliaria quae conscripta sunt in

$20<$ no $>$ mine Caesaris et diui Constantini. nam omnia trifinia de iam dicta[m] Carthagine[m] processerunt. uenit usque ad locum Tormogorum qui et $\mathrm{Or}<\mathrm{e}>\operatorname{tani}$ nuncupa $<\mathrm{n}>$ tur. deinde ad arcam praecipuam quae est in terminos Salamancae cui Durius uicinus commanet flumen. haec arca quattuor < quadris $>$ constructa procedit. quae uidelicet: a dextro Lusitaniam, Baeticam ad postergum; (LITTERAE SENSVS IGNOTI: H L M HT QS QS) Galliciam ad sinistrum; Asturias,

25 Cantabria $<\mathrm{m}>$ nec non et Vasconia $<\mathrm{m}>$ ad facie $<\mathrm{m}>$ quae ad oriente $<\mathrm{m}>$ Carthagini pertinet. deinde procedunt termini, sic $<$ ut $>$ lapides sculptos habentes in se passos LX, qui procedunt usque congeriem petrarum. deinde in passos XXX usque ad lapidem sculptum nomenque praesenti $<\mathrm{s}>$ imperatori $<\mathrm{s}>$ aut domini[s] senatus qui non $\operatorname{arca}<\mathrm{m}>$ sed trifinium diuidunt. deinde $<\mathrm{a}>$ parte orientis incipientes Pyrenaei saltus et a parte septentrionis quod eminet iugum per Vaccaeos usque ad Cantabros Asturesque deducit.

Vlterior uero iam dicta $<\mathrm{Hi}>$ spania habet ab oriente Vaccaeos, Celtiberos et Oretanos, a septentrione et ab occasu Oceanum mare, a meridie Gaditanum Oceani fretum ubi mare terrae inmittitur. (FIGVRA 35: VASCONIA, MARE TYRR $<\mathrm{H}>\mathrm{ENO}$, NARBO, BRIGANTIA CIVITAS, EMPORIAS, BRACARAM, GERVNDA, GADES, BARCINO, TARRACONEM, CARTHAGO) 


\section{CRITICAL APPARATUS}

Main Source: Ms. Ripoll 106, Z 81v 32-82r 24.

Previous edition: chapter 119, pp. 227-230 To.; EHK, pp. 65-66 Th.; pp. 332-333 $M i^{9}$

Secondary sources:

1-5 Ex Oros., hist. I.2.69-72 Zangemeister (= p. 64, 21-25 Riese) $=$ Aeth. Cosmograph. II.33, p. 97-98, Riese; ubi est columna Herculis Ex Oros. hist. I.2.7 Zangemeister (= p. 57, 4-5 Riese)

6 Citeriorem... determinat Ex Oros. hist. I.2.73 Zangemeister (= p. 65, 4-7 Riese $)=$ Aeth. Cosmograph. II.34 (= p. 98, 7-10 Riese).

26-30 orientis... inmittitur Ex Oros., hist. I.2.73-74 Zangemeister (= p. 65, 4-10 Riese)= Aeth. Cosmograph. II.34-35 (= p. 98, 7-13 Riese).

4 Spania $Z$ Th. Hispania To. Oros. om. Aeth. \| uniuerso $Z$-a Oros. \| est $Z$ om. Oros. cf. p. VIII Zangemeister || circumspta $Z$ circumsepta $Z^{1}$ circumfusione Oros. II a mare azeano $Z$ ozeano corr. $Z^{1}$ Oceani Tyrrhenique pelagi Oros. L-Aeth. terrenique $V$-Aeth. 4-5 in duabus... terminatur $Z$ paene insula efficitur Oros. 5 terreno $Z \mathrm{t}$ litteram in uitio folii occultam ipse legere potui in codice. Tyrrheno Th. To. 6 angulis $Z$ angulus To. Oros. I| prior codd. propior B-Oros. (Toneatto) I| spectans... coartatus Oros. post prior om. $Z$ \| in Narbonensium finibus desinit $Z$ Narbonensium finibus inseritur Oros. $\|$ angulus $Z$ u litteram in ipso uitio folii occultam legi 7 uigrancia $Z$ Brigantia Oros. uingrantia VL-Aeth. || ciuitas sita est et altissimum farum $Z$ Gallaeciae ciuitas sita altissimam pharum et inter pauca memorandi operis ad speculam Britanniae erigit Oros. (ciuitas sita est et Galliciae ad VL-Aeth. ciuitas sita est Galliciae et Riese altissimum Aeth. farum mss.) (Toneatto) || eius angulus R-Oros. (Toneatto) || eius est om. Aeth. 7-8 in gadis (gadis $Z^{1}$ To. gadib; fortasse $Z$ (Toneatto) gadi<bu>s Th.) ubi est columna (columne $Z$ columna $Z^{1}$ ) erculis $Z$ ubi apud Gades insulas Herculis (hercule///s D-Oros.) columnae (columnaea D-Oros. -is $D^{2 s v}$-Oros.) uisuntur Oros. 8 et sunt... et ulterior add. $Z$ || Spanie $Z$ Th. To. || ceterior $Z$ Th. ut infra 9 ceteriore spania cartago $Z$ || textus Orosi inter Hispaniam et Carthago ad finem discriptionis Hispaniae transposuit $Z$ (uid. infra) I| hec $Z$ Th. hic To. II iulius $Z$ fortasse ex Fl(auius) To. I| franciscus $Z$ francicus corr. Schulten apud Th. \| giuidisclus $Z$ Gepidicus corr. Schulten apud Th. 10 eropensis $Z$ e $<\mathrm{u}>$ ropensis corr. Th. II castellos oppidos $Z$ <per> castellos oppidos To. castellorum oppidorumque conieci || q; $Z$ que Th. qui To. || metropolitanam $Z \mathbf{1 1}$ iure con. To. || efflumina qui $Z$ et flumina quae Th. To. $\|$ mergebantur prop. Th. $\|$ in ozeano $Z$ in oceanum prop. Th. II demitibit $Z$-metiuit To. -mensus est prop. Th. 12 aut q; terminus palentinus aut cartaginensis aut celtiferus $Z$ a[u]tque terminos Palantinos et Carthaginienses et Celtiberos prop.Th. aut [que] terminos Palentinos aut Cartaginenses aut Celtiberos To. II superiore prouincia $Z$ superiore $<\mathrm{m}>$ prouincia $<\mathrm{m}>$ Th. superiori prouincia To. 13 Gallia $Z$ Gallaecia prop. Th. Galli<ci>a To. || que $Z$ qui To. || ueriam $Z$ Iberiam prop. Th. To. 14 certum

\footnotetext{
${ }^{9}$ See below for full bibliographic details. Other manuscript abbreviations in this apparatus come from secondary source editions (e.g. L-Aeth. means the L manuscript in Riese's edition of the Aeth. Cosmog.).
} 
diuidet $Z$ cercum diuidet $T$. circumdiuidit prop. To. certam conieci || prouincia $Z$ prouincia $<\mathrm{m}>$ To. I| que $Z$ que per Th. $<$ ae $>$ que $T o$. II numancia uardulia cantabria $Z$-am -am -am prop. Th. 15 cartaginense $Z$ Cartaginense $<\mathrm{m}>$ To. $\|$ pertinet $Z$ pertine $<$ n $>$ t To. $\|$ omnem $Z$ omnes pro omnia prop. Th. omnia To. \| cartagine $Z \quad 16$ uenitus q; adter num $Z$ uentumque ad Termem prop. Th. uenit usque ad Ternum secl. To. uenit usque ad ter $<$ mi $>$ num conieci $\|$ betis $Z$ Betis $T h$. To. || cordoba $Z$ Cordoba Th. To. \| <et> conieci || cartago $Z$ Cartago Th. Cartagi<ni>To. 17 betica $Z$ Betica Th. To. I| qui $Z$ quae To. II gadetanum $Z$ Gaditanum To. $\|$ agusta et merita $Z \quad \mathrm{~A}<\mathrm{u}>$ gusta E[t]merita Th. Agusta E[t]merita To. II qui et $Z$ Th. cui [et] To. 18 bracara $Z$ Bracara $<m>$ To. 19-20 inmine cesaris et diuo constantino $Z$ nomine Caesaris et diui Constantini $T h$. in $<\mathrm{n}>$ $<$ n $>$ omine Caesaris et divi Constantini (?) To. 20 omne $Z$ omne $<$ s $>$ pro omnia Th. omnia To. 21 uenitusque ad locum tormogos $Z$ secl. To. uentum est ad locum Tormogos prop. Th Tormogorum conieci \| ortani $Z$ Or<e $>\operatorname{tani}$ Th. To. \| nunccupatur $Z$ nunccupa $<$ n $>$ tur To. 22 salamance $Z$ Salmanticae prop. Th. Salamancae To. || commonet $Z$ commanet $Z^{1} \quad 23$ constricta $Z$ Th. <quadris> constructa To. || procedet $Z$ Th. procedit To. || lusitaniam $Z$ To. Lusitaniae prop. Th. ut infra Baeticae Asturicae Cantabriae Vasconiae || beticam $Z \mathbf{2 4}$ notae inter postergum et Galliciae ad finem uersus decimosexti in codice scriptae sunt capitalibus litteris. HT et QS in nexu, sed -S suprascripta etiam nota abbreuiationis esse posset. || gallicie in rasura $Z$ Gallicie Th. Galliciam To. 25 cantabria $Z$ Cantabria $<\mathrm{m}>$ To. || uuasconia $Z$ Vuasconia To. $\|$ affacie que $Z$ a[f] facieque $T h$. ad facie $<\mathrm{m}>$ To. $\|$ oriente $Z$ oriente $<\mathrm{m}>$ Th. To. \| cartagini $Z \mathbf{2 6}$ sic $<$ ut $>$ To. $\|$ scluptos $Z \|$ se secl.Th. To. 28 presenti imperatori $Z$ praesenti<s> imperatori<s> Th. To. $\|$ dnis senatis $Z$ domini senatus Th. domini[s] senati[s] To. nominis fortasse? $\|$ archa $Z$ archa $<\mathrm{m}>$ Th. To. 29 deinde add. $Z \|$ parte orientis $Z$ ab oriente Oros. $<$ a > parte orientis To. $\|$ incipientes pirinei saltos $Z$ incipientem Pyrenaei saltus Oros. incipientes Pyrinei saltus To. incipit Aeth. pyrenei PR-Oros. pyrinei $D B$-Oros. pirinei $V$-Aeth. pirineis $L$-Aeth. saltibus $V$-Aeth. alpibus $L$-Aeth. (Toneatto) || septentriones $Z$ Th. septentrionis Oros. To. septentrionali Aeth. II qui eminet iugam add. $Z$ quod Th. To eminat $Z$ eminet $Z^{1}$ Th. To. iugam $Z$ iugum Th. To. 30 uacceos $Z \|$ asturesque $Z$ turresque B-Oros. ad turres Aeth. || deducit $Z$ om. Aeth. II atque inde... determinat Oros. om. $Z$ post deducit $\mathbf{3 1}$ Vlterior uero iam dicta spania $Z$ Hispania ulterior Oros. II uacceos celtiferos et osetanos $Z$

Vaccaeos Celtiberos et Oretanos Oros. -ccheos PR-Oros. Baccheos Rec-Oros. Barceos V-Aeth. Harceos L-Aeth. caelteberus D-Oros. cettiberos L-Aeth. orrentanos Aeth. (Toneatto) $\mathbf{3 1 - 3 2}$ a septentrione et ab occasu occeanum $Z$ a septentrione oceanum ab occasu oceanum Oros. oceanum ab occasu om. V-Aeth 32 mare add. $Z$ || gadetanum $Z$ Th. R-Oros. || ubi mare terre inmittitur $Z$ unde mare nostrum quod Tyrrhenum uocatur inmittitur Oros. Tyrr $<\mathrm{h}>\mathrm{e}<\mathrm{num}>$ Th. To. 33 emittitur D-Oros. L-Aeth. 33-35 In tabula ubi Hispaniae rudis imago depicta est VVASCONIA MARE TERRENO NARBONA VIGRANCIA CIVITAS IMPVRIAS BRACARAM IERVMDA GADIS BARCHINONA TERRACHONAM CARTAGO $Z$

\section{Previous editions (with abbreviations in parentheses):}

Toneatto, L. "Note sulla tradizione del Corpus Agrimensorum Romanorum. I Contenuti e struttura dell'Ars Gromatica de Gisemundus (IX sec.).” Mélanges de l'école française de Rome 94 (1982): 191-313. (= To.) 
Thulin, K. Zur Überlieferungsgeschichte des Corpus Agrimensorum. Exzerptenhandschriften und Kompendien. Göteborgs K. Vetenskaps- och Vitterhetssamhälles Handlingar, Fjärde följden, 14. Gothenburg: W. Zachrisson, 1911. (= EHK; pp. $65-66$ = Th.)

Millàs Vallicrosa, J. Assaig d'Història de les idees físiques i matemàtiques a la Catalunya Medieval. Barcelona: Institucio Patxot, 1931. (= Mi.)

\section{Secondary sources:}

Zangemeister, C., ed. Pauli Orosii Historiarum aduersus Paganos libri VII. Leipzig: Teubner, 1889. (= Oros.)

Riese, A. Geographi latini minores. Heilbronn: Henninger, 1878 (repr. Hildesheim: Olms, 1964). (= Riese) 


\section{ENGLISH TRANSLATION}

The whole of Hispania has the shape of a triangle according to the disposition of its land. It is surrounded by the Ocean sea from two sides, that is to say, from north and south. From the east, instead, it is delimited by the Tyrrhenian sea. The first of these angles points to the territory of Narbonenses. The second angle points northwest, where Brigantia and his soaring lighthouse is situated. Its third angle is in Gades, where the Pillar of Hercules is located. At the same time, there are two Hispaniae inside this triangle: Citerior and Ulterior.

Carthage delimits Citerior Hispania. Here Julius Caesar ${ }^{10}$, vanquisher of Franks, Gepids, victorious both in Africa and Europe, established the boundaries of fortresses and towns that belonged to metropolitan jurisdiction and surveyed the rivers that flow into the Ocean.

Regarding the boundaries of the territories of the Palentians, the Carthaginians or Celtiberians', over the furthest province whose name is Gallicia, we preserved all boundary stones built there. Furthermore, the river Ebro, which divides clearly the Province of Iberia, flows through three hundred twenty eight miles. It flows across Numantia, Vardulia and Cantabria, whose land extends to Metropolitan Carthage. Because all trifinia come from Carthage. Unto this boundary comes the river Baetis, where Corduba is situated, and (this territory) receives the name of Carthage. Further comes the Baetica, which reaches as far as the Gaditan fen. Beyond that comes Augusta Emerita which receives also the name of Lusitania. Its boundaries run to the metropolitan city of Bracara, to which Gallicia belongs. There are some boundary stones from the latter which run along stone-paved roads that are marked by miliaria inscribed with the name of Caesar, [and] the divine Constantine. Because all trifinia come from the above mentioned Carthage. (Its territory) reaches the territory of Tormogi, who receive the name of Oretani. Then goes further to a main arca which is in the territory of Salamanca, near to the river Duero. At that point is located this arca with four built sides that point as follows: to the right, Lusitania ${ }^{11}$, beyond that, the Baetica; (UNKNOWN ABBREVIATIONS: $\mathrm{H} \mathrm{L} \mathrm{M} \mathrm{HT} \mathrm{QS} \mathrm{QS}{ }^{12}$ ) to the left, the Gallicia; Asturias, Cantabria as much as Vasconia, on that side which reaches Carthage at east. Then landmarks which have carved stones every sixty steps ${ }^{13}$

\footnotetext{
10 Probably a corruption of Flauius Caesar which could refer to Maurice, in our opinion, or to Justinian, according to Toneatto (1982).

11 Here the words right and left are used in a literal sense and not as synonyms for north and south as is usually the case in land surveyors' texts. To better comprehend the layout of this text, we must place ourselves with the Atlantic Ocean at our back, looking to the east and thus we can understand the description of the arca praecipua. At the right side of the arca is Lusitania and on the left side is Gallicia. The other two sides of the monument point to the territories of Tarraconensis, in the north of the peninsula, and Carthaginiensis.

12 Gisemundus seems to have copied these abbreviations without a clear comprehension of their meaning. This increases the probability that this information may come from Gisemundus' direct observation of the arca and not from an ancient source. The nexi and some abbreviation signs may be of an epigraphic nature.

13 Gisemundus' description of Salmantica has interesting parallels to extant termini. Cortés (2013), 160-167 has collected 91 termini erected by Lucius Minicius Natalis in Numidia, in the second century A.D. that delimited the territory of Musulamii. The terminus from Le Kef (AE 1923, 26; ILTun 1653) mentions the distance between landmark 90 and 91: 116.400 passus. Also the
} 
run unto a stone pile. Then every thirty steps unto a stone carved with that time emperor's name and the authority of the senate. This is not an arca but a trifinium. From that point, at the east, come the first woods of Pyrenees. At north, a hill surges which leads through the Vaccaei to the Cantabrians and the Astures.

In turn, the above mentioned Hispania Ulterior borders to the Vaccaei, the Celtiberians and the Oretani at the east; at north and west to the Ocean sea, at the south to the Gaditan strait of the Ocean, through which the sea gets inside the earth.

fifth landmark from Thala mentions the distance to the sixth: 25.000 passus $(A E 2000,1629)$. It is significant that the distance is indicated in passus, marked with the number XXV and the superior line that usually indicated means thousands (mille passus equals more or less a mile). According to these parallels, it is possible that the short distances of 60 and 30 passus mentioned in the Discriptio could originally have indicated milia passuum, i.e. miles, a detail that was probably lost due to error or misunderstanding by later copyists. 


\section{The Discriptio Hispaniae and the Byzantine presence in Spain}

Previous research has showed the accuracy of the information that Gisemundus used in the Discriptio; for instance, the reference to Gallicia as provincia Superior, to Constantine's milestones, and to the role of Salmantica and the Duero river as provincial boundaries. ${ }^{14}$ All of this information probably comes from official documentation from the second to fourth century. The precision with which Gisemundus deployed early imperial and late antique material suggests that he might also provide accurate information from other sources. The rest of this article seeks to establish that the most likely point of origin for the Discriptio Hispaniae is during the Byzantine occupation of parts of southern Spain during the second half of the sixth century and the first quarter of the seventh century. We suggest that the Discriptio Hispaniae was preserved because the Byzantine authorities were keen to keep on record information about the borders of the province of Carthaginensis, perhaps the main theme in the text. In the early 550s the forces of the Byzantine Emperor Justinian (527-565) had established a foothold in Spain, establishing a province called Spania that was governed from Cartagena, capital of the Roman province of Carthaginiensis. As the internal borders of Hispania originated in the Augustan period, initially as a conventus and later as the boundaries of separate provinces after Diocletian's reforms, it was necessary to preserve as much of the agrimensorial information about the limits of (and within) Hispania as possible. This had the potential to support any claims that the Byzantines wanted to make on the territory that traditionally pertained to Cartagena.

There are a number of different factors that support our ascription of the Discriptio Hispaniae to the period of Byzantine occupation. First, the reference to 'Julius Caesar, vanquisher of Franks, Gepids, also in Africa and Europe', who established the boundaries of several castella et oppida, is crucial to establishing the chronology. The elements of the formula are confusing and corrupt, and there is no Roman emperor who used exactly these honorific epithets. ${ }^{15}$ Toneatto proposed Byzantine emperors as the best option and as the Byzantines occupied parts of southern Hispania for a relatively short period of time, from 552 to 625 , the list of potential candidates is relatively short. Iulius is likely a confusion for Flavius, misunderstood from an abreviation. Europensis is an invention, probably linked to the precedent Africanus, and Gepidicus appeared to be corrupted.

Thulin (1911) was the first to propose Justinian as the most viable option. Toneato agreed, but suggested that Maurice (582-602) was also a viable possibility. ${ }^{16}$ Justinian could have used the title Gepidicus, although it is not mentioned in any other source, due to the victory of his Longobard allies over the Gepids. ${ }^{17}$ However, Maurice used the formula Caesar Flavius Francicus Gepidicus Afric(an)us, which closer to the text in our manuscript, and the same

\footnotetext{
14 Olesti and Andreu (2016).

15 Toneatto (1982), 262.

16 Toneatto (1982), 262.

${ }^{17}$ In fact, Justin II and Tiberius II also used the formula Caesar Flavius Francicus Africanus.
} 
formula was also used by Phocas (602-610) and Heraclius (610-641). ${ }^{18}$ The (limited) evidence that we have for the Byzantine presence in Spain does not suggest that the province was of much interest to Phocas and Heraclius - not to mention Justin II (565-578) and Tiberius II (578-582). It was certainly not a priority, and both Thulin and Toneatto therefore ruled them out.

Thulin and Toneatto thus opted for Justinian on the likely existence of a treaty that Justinian entered into with Athanagild, the rebel and later king (r. 554-567) who invited the Byzantines to intervene in Hispania. However, the formula preserved in the $A G G$ is actually closer to the titles adopted by Maurice, and epigraphic evidence points unequivocally to active intervention of the government of Maurice in Cartagena at the end of the sixth century, under the auspices of the governor Comitiolus. ${ }^{19}$

The second element pointing towards the Byzantine origin of the Discriptio Hispaniae is the reference to Carthago (Cartagena, also known as Carthago Spartaria) as metropolitana (ad Carthaginiensem metropolitanam pertinent). ${ }^{20}$ The rank of metropolitan pertains to the chief city of a Roman province, regional capital, or ecclesiastical province (the diocesan bishop or archbishop of a metropolis). The Discriptio Hispaniae mentions the metropolitan status of Braccara (i.e. Braga, over Gallaecia) and Carthago (i.e. Cartagena, over Carthaginiensis, under Byzantine control in the posited period of composition).

The Visigoths, who controlled the most of the territory of Carthaginiensis by the time that the Byzantines intervened there, were not in possession of the ecclesiastical and traditional civil capital of the province, Cartagena. This disjunction must have informed the decision of the kings to promote the status of Toledo, the city that emerged as capital of their kingdom in the later sixth century. In the early seventh century, for example, the bishop of the city was promoted to the status of metropolitan over Carthaginiensis.

From the Byzantine point of view, the Discriptio Hispaniae's double reference to the Metropolitana Carthago, emphasised the historical status of the capital of Byzantine Spain, underlined the legitimacy of the claim to territorial control over Carthaginiensis and suggested not only the administrative dominance of Cartagena but also its ecclesiastical pre-eminence. ${ }^{21}$ In other words, mentioning metropolitan status of Cartagena over Carthaginiensis stressed the status of the main Byzantine city and suggested that the cities that were under Visigothic control were its subordinates.

\footnotetext{
18 Feisell (2011).

19 CIL II, 3420.

20 The document does not use the place-name Carthago Spartaria, as mentioned in other late antique and earlier sources (e.g. It. Ant. 401, 5; Plin. HN. 31, 43). It is unlikely that the Carthago referred to here is the capital of Byzantine Africa because, e.g., George of Cyprus refers to African

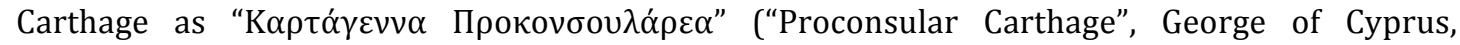
Descriptio Orbis Romani, 640-641) to distinguish it from city in Hispania; Vallejo (2012), 292.

${ }^{21}$ Olesti and Andreu (2016).
} 
The third and most important point in favour of the theory of a Byzantine origin for the Discriptio Hispaniae is the information that the source gives about the territorial limits of Carthaginiensis. On several occasions the text refers to the borders of the province, emphasising the role of Cartagena as its capital and central point. :

1. Line 9: "Carthage delimits Citerior Hispania".

2. Lines 10-11: (the emperor) "established the boundaries of castles and fortified towns that belonged to metropolitan jurisdiction and surveyed the rivers that flow into the Ocean".

3. Lines 12-13: "Regarding the boundaries of Palentia's, Carthage's or Celtiberians' territories (...) we preserved all boundary stones built there",

4. Lines 13-16: (the Ebro river) "flows across Numantia, Vardulia and Cantabria, whose land extends to Metropolitan Carthage. Because all trifinia come from Carthage. Unto this boundary comes the river Baetis, where Corduba is situated, and (this territory) receives the name of Carthage".

5. Lines 20-21: "Because all trifinia come from the above mentioned Carthage".

6. Line 25: (arca praecipua) "on that side which reaches Carthage at east".

Cartagena functions in the text (extracts 1, 2-6) as the origin of all territorial delimitations (boundaries, trifinia, arca praecipua). This reflects the legal terminology and procedures laid down by Roman agrimensores, and thus emphasises the legitimacy of the city's claim to authority over these areas. The underlying argument is clear: because the Byzantine controlled the provincial capital, all the territories inside their borders, delimited from Cartagena, belonged to them.

In the text of the Discriptio Hispaniae there are three specific references that may well relate to agrimensorial activity: "Carthago delimits (determinat) Citerior Hispania" (extract 1 above); and (the emperor) "established the boundaries of fortresses and towns that belonged to metropolitan jurisdiction and surveyed the rivers that flow into the Ocean" (extract 2 above). The precision of these references is indicative of some kind of official activity. Determinatio, for instance, is an agrimensorial term, describing the process by which a territory was delimited and measured before the terminatio - a second operation involving the erection of the termini of the land that had previously been measured - took place. ${ }^{22}$ The Discriptio Hispaniae thus suggests that the province was measured and its limits defined according to an official procedure, or at least that whoever put the text together wanted to give the impression of official sanction.

The second extract above mentions the division of the territory into castella et oppida, terms there were used across the Roman, late antique and Byzantine periods. ${ }^{23}$ These terms were related to the concept of the civitas, in which a

\footnotetext{
22 Arnaud (2006).

23 These terms appeared in some Late Republican laws, as the Lex Rubria de Gallia Cisalpina, XXI, 1-2 (CIL XI, 1146). As we shall see, in the Visigothic period, John of Biclarum, the late-sixthcentury chronicler, used similar vocabulary.
} 
political (urban?) centre was linked to a dependent territory for administrative purposes. The use demetiuit to refer to rivers flowing into the ocean and further references to rivers (extracts 2 and 4 ) is also suggestive of land measurement. The practice of measuring rivers as a means of demarcating land boundaries is a common feature of Roman agrimensorial treaties. However, it was by no means infallible because changes in the courses of rivers had the potential to generate conflict over changed boundaries.

The preceding sections have suggested that text known as the Discriptio Hispaniae, a small part of the agrimensorial collection put together by Gisemundus in the ninth century, contains information pertaining to the Byzantine presence in the Iberian Peninsula. In addition, we propose that it probably that originates sometime in the reign of the Emperor Maurice and reflects the efforts of the Byzantine government in Spania to establish their authority over the province of Carthaginiensis, most of which was actually under Visigothic control. In what follows we provide an overview of how this suggestion might affect interpretations of various aspects of the history of Spania, including its boundaries, government and defences. Evidence from the Discriptio Hispaniae is related to existing sources of information about the province. The new material confirms a number of existing hypotheses, develops others and challenges some longstanding interpretations of the period. This analysis has the added benefit of better contextualising the Discriptio Hispaniae historically.

\section{Evidence for the 'frontier' and defences of Spania}

There has been considerable debate over the extent to which the Byzantine province was defended by an organised frontier system, or limes. Some scholars suggest that the Byzantines established a so-called 'double limes' as they seem to have done in north Africa. Such a system would have been constituted in two layers: first, the main walled cities (urbes) of the province; second, a series of smaller fortified sites (castra, castella) in the interior. ${ }^{24}$ Others have argued that there was no need for an organised system because Byzantine control did not extend very far into the interior of the Iberian Peninsula and was instead focused on the coastal cities (mainly Cartagena and Malaga) and their immediate hinterlands. ${ }^{25}$ An intermediary position is that there is sufficient evidence to suggest the Byzantine control did extend into the interior at various points in the history of Spania, that the defence of the province was taken seriously by the government, including limited construction of fortifications, but that there is insufficient evidence to prove that a frontier 'system' was established. ${ }^{26}$

Whichever of these interpretive frameworks is favoured, it is clear that the borders of Byzantine territory - whether fortified or not, whether systematised or not - developed over time, as did the geographical extent of the province and the degree which the imperial government was able to control and exploit its human and material resources. It is clear, for instance, that Visigothic power did not extend very far into the south of the Iberian Peninsula in the mid-550s, the

\footnotetext{
${ }^{24}$ García Moreno (1973), 5-22.

25 Ripoll (2000), 95-116.

26 Wood (2010), 292-319.
} 
point at which the initial Byzantine incursions took place. Much of the south seems to have been under the control of local aristocracies and focused on the major cities of late Roman Hispania, such as Cordoba and Merida. ${ }^{27}$ In the early days of Spania, therefore, there was no frontier with the Visigoths because there were few (or no) Visigoths for form a boundary against.

The reign of King Leovigild (568-586) marked a turning point. Under Leovigild's leadership, the Visigoths established themselves as the dominant military force within Hispania, bringing peripheral regions that had formerly been autonomous under control in north and south, as well as conquering the Suevic kingdom in Gallaecia. Leovigild also conducted campaigns against Spania and during his rule it is likely that there emerged a clearer sense of the limits of Byzantine control. References to military conflicts and other kinds of contacts between Byzantines and Visigoths thus increase from the reign of Leovigild onwards.

We saw above how the Discriptio Hispaniae emphasised that castella and oppida had been set up at the boundaries (termini) of the province. Particularly important for the debate over the nature of the frontier between the two competing powers are some references in the Chronicle of John of Biclarum relating to the reign of Leovigild in which he twice discusses the capture of cities and fortresses (urbes, ciuitates, castella) to the Visigoths. ${ }^{28}$ It is important to note that John is not talking about Visigothic or Byzantine lands here, but the conquest of territory controlled by the city of Cordoba and the region of Orospeda, both of which had been operating independently of external rule. The fact that John of Biclarum had been educated at Constantinople may perhaps have influenced the choice of this specific terminology, reflecting some knowledge of imperial technical terminology for the organisation of territory around urban sites. However, it is also important to note that John of Biclarum does not deploy the same specific terminology as is used in the Discriptio Hispaniae, making no reference to oppida at all.

The definitions of castellum and oppidum in Isidore of Seville's Etymologies, published in the late 620s, make clear that they served defensive purposes, although they were also defined by their roles as population centres and as places for the collection of resources. ${ }^{29}$ Despite their different meanings, Isidore does seem to place urbs, oppidum and ciuitas on the same level, one step above castellum. This may indicate that the expressions urbes et castella and ciuitates et castella (both in John of Biclarum) and oppida et castella (in Gisemundus and others) are equivalent. Given these various contexts, the reference that the Discriptio Hispaniae makes to the setting up of castella and oppida at the boundaries (termini) of the province pertaining to the metropolitan authority is thus significant, but not conclusive, potentially supporting the idea of a coordinated attempt to organise the province's frontier defences.

\footnotetext{
27 Kulikowski (2004), 274-275; 282-284.

28 John of Biclarum, Chronicle 20, s. a. 571: multasque urbes et castella interfecta rusticorum multitudine, in Gothorum dominium reuocat; 46, s. a. 576: Leouigildus rex Orospedam ingreditur, et ciuitates atque castella eiusdem prouinciae occupat, Cardelle de Hartmann, ed. (2001), 63, 69.

${ }^{29}$ Isidore, Etymologies 15.2.5-6; 15.2.13, Lindsay, ed. (1911).
} 
The Discriptio Hispaniae contains some indications about the boundaries of the province of Carthaginiensis, including the Ebro Valley to the north, the borders of the provinces of the Baetica and Lusitania to the south, using agrimensorial technical terms such as the arca praecipua, and emphasising the role of Salmantica as a territorial trifinium. While this represents a more-or-less accurate delineation of the borders of the Roman and late antique province of Carthaginiensis, it bears no relation to the actual extent of Spania. For one thing, it makes no reference to the territory that we know the Byzantines controlled in the south of the province of Baetica.

It is likely that, as part of the agreement that was made with Athanagild in exchange for assistance in a Visigothic civil war in the early 550s, the Byzantines took over some coastal cities in the south and extended their control inland. ${ }^{30}$ However, even we restrict our analysis to the holdings in Carthaginiensis, it is extremely unlikely that Byzantine control extended as far north as Salmantica and Palentia, especially given the fact that recorded conflicts with the Visigoths occurred much further south, within the province of Baetica, in fact, rather than Carthaginiensis. The Discriptio Hispaniae refers to the River Guadalquivir and Cordoba (at line 16: uenit usque ad ter $<$ mi $>$ num Baetis ubi Corduba sita est <et> Carthago nuncupatur), a city that, although we have no evidence of Byzantine control, may have come under imperial influence and which Leovigild strove to bring under Visigothic control, succeeding in ca. 572. This reinforces the impression that when the Discriptio Hispaniae was written down the approximate limit of Byzantine and Visigothic spheres of influence (if not actual control) was situated somewhere in the south of the basin of the Guadalquivir. ${ }^{31}$

The castella and oppida of the Discriptio Hispaniae are certainly worthy of further investigation, but do not offer unequivocal support for any of the frontier hypotheses outlined above, although, by suggesting that the imperial authorities were interested in projecting their authority at the borders of the province, they do to some extent compromise the idea that Byzantine control was limited to the coastal cities. If the document does date to the 590s, then it only suggests that organised frontier defences were in place at that time, not necessarily earlier and by no means undermines the suggestion that the reign of Leovigild was the key turning point. Second, given that the boundaries that are proposed for the province cannot possibly represent its actual limits in the 590s, this puts into question the veracity of other specific details. The Discriptio Hispaniae may thus represent a rhetorical claim about the limits and form of Spania's boundaries, rather than an attempt to record them accurately. Third, the castella and oppida do not offer unequivocal support to the theory of an organised frontier with two 'layers'. Although the source suggests that defences were organised around population centres at the border itself, there is no reference to an interior line based on the major cities of the province, or to how the defences were articulated in the intermediary zone. It is important to note the emphasis that is placed on the coordinating effort of the metropolitan, which is indicative of a

${ }^{30}$ Vallejo (2012), 160; Jiménez and Ribera (2014).

31 Olesti and Andreu (2016). 
more thorough administration of the province than has often been imagined in the past. We will return to the issue of the administration of the province later in this chapter.

\section{Archaeological evidence and material culture}

Scattered references in the literary sources point to military activity in the areas in which the Byzantines and Visigoths came into contact, especially in the reign of Leovigild and afterwards, while epigraphy allows us to identify at least one occasion on which the defences of Cartagena, the capital of Spania, were reinforced. ${ }^{32}$ Archaeological excavations conducted over the past thirty years have enabled scholars to refine their interpretations of the material impact of the Byzantine presence in Spania and the Iberian Peninsula more generally. At Cartagena, for example, defensive construction has been suggested for the period of the Byzantine presence, while the discovery of military equipment provides evidence for the presence of troops in the city. ${ }^{33}$

It is clear that there was a considerable amount of traffic between Byzantine and Visigothic territory. The material record suggests that, although the scale of interaction between the cities of the Iberian Peninsula and broader Mediterranean trading networks was reduced during the fifth and sixth centuries, there was continued contact with parts of the Byzantine West and even with the eastern Mediterranean. Sometimes such contacts are evident in the written sources or inscriptions. Port and trading cities, even those as far afield as Braga in the north-west, maintained these connections longest, but in general it was areas under Byzantine rule that remained integrated into Mediterranean networks later than Visigothic-controlled cities. ${ }^{34}$

While it has been relatively straightforward to discover 'Byzantine' influence on or contact with specific sites via the material record, it is more problematic to identify archaeologically whether such places were actually controlled by the empire. Even when written sources refer to a Byzantine or Visigothic presence at a city, the lack of diagnostic materials or detailed chronologies, the fragmentary nature of the literary record, as well as the fact that the boundaries of Spania are likely to have changed over time mean that it is extremely difficult to determine which political power was in control of a particular site at a given moment in time.

A good example is Basti, an Ibero-Roman site near to the modern day city of Baza. Basti, along with the city of Acci (modern Guadix), played an important role in controlling the key Roman road in the south, the Via Augusta, which connected the cities of Cartagena and Málaga, also facilitating access between the coast and the valleys of the Guadalquivir and Genil rivers. Basti also dominated the agricultural hinterland known nowadays as the Hoya de Baza. Excavations at Cerro Cepero have demonstrated that the site was occupied during the sixth and seventh centuries, including possible remains of a Christian church based on

\footnotetext{
32 Prego de Lis (2000).

33 Vizcaíno Sánchez (2015), 187.

34 Reynolds (2010), 120-130.
} 
structures from the imperial period. ${ }^{35}$ In 570, King Leovigild launched a campaign against the region of Bastetania and the city of Malaca (modern Málaga), defeating imperial troops and returning victorious. ${ }^{36}$ This suggests, but does not prove definitively, that Basti was taken during the initial Byzantine intervention in the Iberian Peninsula in the 550s, developed as a strong point that controlled the communications network within imperial territory. Leovigild therefore targeted the city as part of an assault on the Byzantine territory in 570 because it was necessary to subdue Basti in order to assault Málaga effectively. It is important to note that over the course of the next decade Leovigild took over areas that neighboured Basti and had not previously been under Visigothic rule: the city and territory of Cordoba to the west, in 571; and the region of Orospeda to the north-east, in $576 .{ }^{37}$ It is unlikely that Malaga fell to the Visigoths at this point in time, because there is strong evidence for Byzantine control there in the 590s. The attack on Basti and Malaga in 570 may well have been a raid, perhaps intended to prevent the Byzantines from intervening when Leovigild sought to conquer neighbouring independent territories. It is clear, that, whether or not Basti was taken permanently by Leovigild in 570, both Basti and Acci had fallen to the Visigoths either by the early stages of King Reccared's reign (586-601) because their bishops, Theodorus and Lilliosus subscribed to the acts of the Third Council of Toledo in 589. The order in which they subscribed to the acts indicates that they were relatively junior, suggesting that they had been recently appointed, perhaps because their sees were newly integrated into the ecclesiastical infrastructure on the Visigothic side of the border. ${ }^{38}$

Similarities have been identified between Basti and other sites in the border between the territories of the Visigoths and the Byzantines, including: occupation of defensive sites at height; development of new and existing fortifications; urban development; ecclesiastical construction; control of communications networks; control of sites of mineral extraction and/or rich agricultural territory. ${ }^{39}$ As was noted above, at Basti and other inland sites, further interpretation is often hampered by a lack of extensive excavations, difficulties in developing absolute and relative chronologies, and the paucity of the written record. While Basti was probably part of the Byzantine province initially and later came under Visigothic control, it is difficult to pinpoint exactly when this occurred and it is entirely possible that it changed hands on more than one occasion. The site potentially played a defensive role, in dominating access from the interior to the coast (and vice versa), as is illustrated by Leovigild's campaign in 570 , but this does not mean that it did not also serve a wide range of other functions in terms of enabling the Byzantine (and later Visigothic) administration to extract resources through taxation, for instance, and to control the local population.

\footnotetext{
${ }^{35}$ A stone altar referring to bishop Eusebius of Basti (633) has been found at the nearby site of Cerro del Quemao, Caballero, Gimeno, Ramírez and Sastre (2006).

${ }^{36}$ John of Biclarum, Chronicle 12, s. a. 569, Cardelle de Hartmann, ed. (2001), 62: Leouegildus rex loca Bastanie et Malacitane urbis repulsis militibus uastat, et uictor solio redit.

37 John of Biclarum, Chronicle 20, s. a. 571; 46, s. a. 576, Cardelle de Hartmann, ed. (2001), 63, 69.

Salvador Ventura (2002).

${ }^{38}$ García Moreno (1974), 152; García Moreno (2008), 79.

${ }^{39}$ Abad Casal and Gutiérrez Lloret (1997); Abad Casal, Gutiérrez Lloret, Gamo Parras and

Cánovas Guillén (2008); Salvador Oyonate, Wood and Caballero Cobos (forthcoming).
} 
The references in the Discriptio Hispaniae to rivers and to defensive sites indicate that the Byzantine authorities were keen to establish and record their control of territory, especially along the borders, yet it is very difficult to tie this and other sources to the material record on the ground or to specific sites like Basti. As we shall see later, the Byzantines seem to have wanted to exploit the resources of Spania, and the recording of its specific geographical features would have been an effective means of achieving this end. The borderlands between Byzantine and Visigothic territory were thus not simply linear frontiers or zones in which interaction took place between the regional powers of the day, but spaces in which were occupied by local elites and populations. It is the presence of such populations, alongside the strategic importance of the lands that they inhabited, which simultaneously challenged Visigothic and Byzantine rule, made the borderlands worth fighting over and perhaps made it even more important that attempts were made to record claims to territory by competing elites.

\section{Evidence for diplomatic activity}

In addition to the material evidence for continued connectivity across the 'border' between Byzantine and Visigothic territory, there are a number of references to diplomatic interactions that may be helpful in comprehending the production of the Discriptio Hispaniae.

Isidore of Seville mentioned that Athanagild requested military assistance (militum auxilia) from Justinian when he launched his rebellion against King Agila in the early 550s. Although scholars have assumed that at a treaty was signed between Athanagild and Justinian, no contemporary source mentions a treaty and no such document survives. It is likely that the purported treaty would have been based on the kind of information that is contained in the Discriptio Hispaniae. ${ }^{40}$ Another interesting episode is an exchange of letters between Pope Gregory I and the Visigothic King Reccared in 599.41 Reccared requested that Gregory inquire with imperial authorities about obtaining a copy of an earlier treaty between the Visigoths and the Byzantines. This may have a treaty that was concluded in the 550s, establishing the terms for Byzantine intervention in Spain. Presumably the treaty would also have outlined the territorial limits of Byzantine rule and this is one of the points in favour of the hypothesis that the Discriptio Hispaniae originates from an agreement between Justinian and Athanagild. According to Gregory, the original document was lost in a fire in the Imperial archives in Constantinople. The pope advised Reccared that his demand would not be advantageous, probably because the rights of the Byzantines in the original treaty included more territories than they effectivelly controlled in 599.

On the basis of the available evidence, it is impossible to confirm whether the Discriptio Hispaniae dates originally to the 550s and was somehow related to the treaty between Justinian and Athanagild. But it is clear that Gregory was able to access information about the treaty and the present limits of Spania, and knew

\footnotetext{
40 Vallejo (2012), 160.

${ }^{41}$ Gregory I, Registrum Epistolarum, IX, no. 229, Hartmann, ed. (1899), 225-6; Vallejo (1996).
} 
that the original had been destroyed. Whether or not Justinian's government fed information like that included in the Discriptio Hispaniae into the production of the treaty of 552 is impossible to ascertain, but it is clear that at the end of the 590s sufficient information was available to enable Gregory to compare the situation in the 550s with that in the 590s.

The Discriptio Hispaniae, if it does indeed outline the territorial limits of Justinianic-era Byzantine Carthaginiensis, was ill-aligned with the political realities of the 590s, when Visigothic power had expanded southwards and Byzantine authority was limited to a coastal strip and a few territories inland. In addition to the evidence outlined earlier in this chapter, there is further circumstantial evidence that it is in the 590s that the production of the Discriptio Hispaniae should be placed. ${ }^{42}$ The 590 s and the following two decades are the period for which we possess the most evidence of diplomatic interaction between the Byzantines and the Visigoths through the exchange of letters and embassies.

The letters exchanged between Reccared and Gregory refer to an earlier treaty, not specifically to the one agreed between Athanagild and Justinian. The Gregory-Reccared interaction took place in a decade in which VisigothicByzantine relations entered a new phase. The conversion of the Visigoths from Arianism to Nicene Christianity in 589 seems to have resulted in an increase in anxiety on the part of the Byzantine government concerning the loyalty of the Nicene population of Spania. The imperial government seems to have been particularly concerned about connections between bishops in Spania and those in the Visigothic kingdom. ${ }^{43}$ At the same time, the administration of the Emperor Maurice adopted an increasingly militant attitude towards the Visigoths. The most well-known evidence for upsurge in Byzantine activity is the inscription of the governor Comentiolus, raised in Cartagena, the provincial capital, in $589 / 90.44$ The inscription is a forceful statement of the permanence of Byzantine rule in Spania and of their superiority over their 'barbarian enemies' (hostis barbarus; i.e. the Visigoths).

The 590s may also have witnessed some Visigothic successes against the Byzantines, providing an impetus to further diplomatic interactions. It is entirely possible that the activities of Comentiolus, an experienced commander, were intended to bolster the military establishment of Spania. Indeed, the inscription commemorates the reinforcement of the fortifications at Cartagena. In this context, it has been argued that Reccared's letter to Gregory may have been an effort to use an old treaty as leverage in negotiations over lands that the Visigoths had conquered recently. ${ }^{45}$ Building on this interpretation, we suggest that the Discriptio Hispaniae was put together in the 590s in the context of Byzantine-Visigothic disputes over the historical and contemporary extent of their territories. Given Gregory's statement that the former treaty was

\footnotetext{
42 On diplomatic contacts between Byzantine and Visigothic Spain, see: Claude (1996); Vallejo (1997), 72-79; Wood (2010).

43 Vallejo (1993), 424-425.

44 Prego de Lis (2000).

45 Claude (1996), 18-19.
} 
disadvantageous to the Visigoths, it is possible that the Discriptio Hispaniae drew on an older document that vastly over-estimated the extent of Byzantine holdings in Carthaginiensis.

Whether or not one accepts a date in the early 550s or the late 590s, information derived from provincial agrimensorial texts of the kind contained in the Discriptio Hispaniae, would have ben fundamental for defining precisely provincial borders. Such information demonstrates the intelligent use to which Byzantine officials were able to make of official documentation long after the fall of the Western Roman Empire. Of course, the Byzantines cannot have expected the Visigoths to agree with their argument, but texts like the Discriptio Hispaniae would have proved useful in diplomatic negotiations with the Visigoths and propagandistic efforts to emphasise the historical legitimacy of Byzantine claims to the entirety of the province.

\section{Evidence for the government of Spania}

Leander of Seville's De institutione virginum et contemptu mundi, written to his sister Florentina, at some point in the second half of the sixth century, outlines the challenges and benefits of living a communal life with other nuns. Towards the end of the work, however, Leander speaks at length about the devastation that his homeland has suffered:

Ego tamen expertus loquar, sic perdidisse statum et speciem illam patriam, ut nec liber in ea quisquam supersit, nec terra ipsa solita sit ubertate fecunda. Et non sine Dei iudicio. Terra enim cui ciues erepti sunt et concessi extranei, mox ut dignitatem perdidit, caruit et fecunditatem. I speak from experience when I say that that country has so completely lost its rank and its beauty that there is not a single free person left in it, nor is the land itself as fertile as usual. And that not without the judgement of God. That land, whence citizens were carried off and sent abroad, lost its fertility as soon as it lost its dignity. ${ }^{46}$

The biography of Leander that was written by Isidore of Seville, his brother, in the early seventh century, states that he came from Carthaginiensis. ${ }^{47}$ It has been argued that the family moved to Baetica in the context of conflicts between Visigoths and Byzantines in the third quarter of the sixth century. Leander's two brothers, Isidore and Fulgentius, also became bishops in Baetica- of Seville and Ecija respectively - in the early seventh century. ${ }^{48}$ Both Carthaginiensis and Baetica were within the Byzantine sphere of influence, much of the coastal parts of the provinces was under direct Byazantine control. In the 580s Leander acted as ambassador for the Visigothic rebel prince Hermenegild to the Byzantine court in Constantinople and was the leading ecclesiastical figure at the Third Council of Toledo, held in 589, which celebrated the conversion of King Reccared and the Visigoths to Nicene orthodoxy. ${ }^{49}$ Leander's complaint about the lack of

\footnotetext{
${ }^{46}$ Leander, The training of nuns and the contempt of the world, 31 (translation modified from Barlow (1969), 226-227), Campos Ruiz and Roca Melia, eds. (1971), 74.

47 Isidore, De viris illustribus 28: Carthaginiensis prouinciae Hispaniae, Codoñer Merino, ed. (1964), 149.

48 Fontaine and Cazier (1983).

${ }^{49}$ Wood (2010), 311, 314-315, 317.
} 
liberty in his homeland under imperial rule may thus reflect his frustration at the failed alliance of Nicene bishops and the Byzantine government of Spania.

The reconciliation of Iberian episcopacy and Visigothic monarchy after the conversion of Reccared, accompanied by open hostility to the Byzantines, finds expression in the writings of other Nicene bishops. Isidore was later to thrown his considerable rhetorical weight behind the Nicene Visigoths against the Byzantines in a series of historical works. In these works he consistently emphasises the negative material effects of Roman (i.e. Byzantine) rule and the positive impact of Visigothic control. For example, the first redaction of the History of the Goths, written in the mid-610s, states that those who had come under Visigothic control after the sack of Rome in 410 preferred Visigothic domination to that of the Romans:

Unde et hucusque Romani, qui in regno Gothorum consistunt, adeo eos amplectuntur, ut melius sit illis cum Gothis pauperes uiuere quam inter Romanos potentes esse et graue iugum tributi portare.

'And from then up to this point in time the Romans, who remain in the kingdom of the Goths, embrace them to such a degree that it is better for them to live poor with the Goths than to be powerful among the Romans and bear the heavy yoke of tribute.'50

It is hard to read this extract as anything other than an attack on contemporary Byzantine rule in Spain and the burden of taxation imposed by the empire.

Leander acted as an envoy to Constantinople in the early 580s, but he later threw his support behind the Visigothic monarchy after their conversion to the Nicene position. It is clear that after the conversion, criticisms of Byzantine rule in Spain focused on the detrimental effect that it had on the wealth and freedom of the people and the fertility of the territory of Spania. Criticisms of the avariciousness of imperial tax officials were common in late antiquity, while God's displeasure was also frequently depicted as manifesting itself physically, for example in natural disasters. Leander's emphasis of the loss of fertility of his homeland is simply a milder form of such interpretive paradigms, while Isidore's attack on excessive tax burdens was not out of the ordinary either.

While we must be wary of the tropes that underlie these depictions of life in Spania, they may reflect the fact that the administration of the province was actually quite similar to the rest of the Byzantine Empire. Although the sum total of evidence for Spania is relatively small, we do possess evidence for how the province was administered. It is likely that the province was under the jurisdiction of the exarchate of Africa, governed from Carthage. There are references to a number of governors of patrician rank, including Comentiolus and Caesarius. Sources mention judges and Roman civil law was in operation within the province. There are references to treaties between the empire and the Visigoths in Spain, while number of different figures are known to have acted as intermediaries between the government of Spania and other authorities such as the Visigothic kings and the imperial regime in Constantinople, including:

\footnotetext{
${ }^{50}$ Isidore, History of the Goths, first redaction, 15 (my translation); Rodríguez Alonso, ed. (1975),
} 196. 
merchants, priests, bishops, and popes. ${ }^{51}$ In addition, it is probable that coinage was being minted in Spania and an increasing number of official Byzantine weights (pondera) have been discovered in sixth and seventh century contexts across the Iberian Peninsula, particularly in the south. ${ }^{52}$ This suggests that trade was taking place, with some degree of official oversight, between the province and other Byzantine territories, as well as with Visigothic-controlled areas.

There are grounds for thinking that the Byzantines were interested in measuring and delineating the boundaries of their holdings in the Iberian Peninsula. As we have already seen, this may have been for rhetorical purposes, to counter Visigothic claims to hegemony over the south of Hispania. However, we should not exclude the possibility that the measurement of the province served a practical purpose, allowing the imperial government to administer and exploit the territory over which they governed more effectively. Other contemporary texts, more well-known than the Discriptio Hispaniae, also outline the provinces and boundaries of the Byzantine Empire or of other aspects of its human and physical geography. In such sources, rivers are often identified as key geographical features..$^{53}$ The importance that the Discriptio Hispaniae ascribes to the Ebro and Duero rivers as major boundary markers is thus entirely in keeping with the Byzantine geographical tradition. In this context, a reference in the Descriptio Orbis Romani of George of Cyprus, an early seventh century text, is interesting. George refers to 'mesopotamia'. Vallejo interpreted this as a reference to the territory of Algeciras, or perhaps the "Mar Menor" (North of Cartagena), both areas extremely marshy land.54 Scholars have also examined Stephen of Byzantium's Ethnica of the sixth century, although they have been unable to identify any direct reference to the Byzantine holdings in the Iberian Peninsula. ${ }^{55}$ Therefore, although the Discriptio Hispaniae cannot be connected definitively to the Byzantine geographical tradition, it is worth interpreting the text in the light of a broader late antique interest in geography. The Discriptio Hispaniae was doubly significant, as it potentially opposed Visigothic expansionism and supported the efforts of imperial officials to manage the territories under their control.

The Discriptio Hispaniae, when viewed in the context of these other pieces of evidence, suggest that the administration of Spania was not just interested in preserving late Roman provincial boundaries but also in developing the province. The bureaucracy was as widespread and perhaps, following Leander and Isidore, as oppressive as that which was found across the rest of the Byzantine West. It is clear, therefore, that the Byzantine administration of Spania had the resources to produce and archive a document such as the Discriptio Hispaniae and it is entirely possible that this was linked to the government's efforts to manage and exploit the territory over which it ruled.

\section{Evidence for the organisation of the church in Spania}

\footnotetext{
51 Wood (2010).

52 Vizcaíno Sánchez (2013).

53 Vallejo (2012), 289.

54 Vallejo (2012), 291-291 also mentions the possibility of a misunderstanding by the author.

55 González Blanco (1991).
} 
In 619 the bishops of the province of Baetica met at the Second Council of Seville and dealt, among other matters of ecclesiastical discipline, with issues relating to the recent conquest of Byzantine territory by the Visigoths. Particularly important for the purposes of this chapter is the first canon, which dealt with a conflict over the diocese of Malaga recently taken from the Byzantines. It seems that when Malaga had been part of Spania, those parts of the diocese that fell under Visigothic control had been divided between the bishops of Écija, Elvira and Cabra. The council ruled that because the whole diocese was under Visigothic control the two other bishops should return churches to the jurisdiction of Malaga on the principle of postliminium. Like the sources examined in the previous section, the council, presided over by Isidore, stressed the negative effects of Byzantine rule on the material welfare of the territory that had been under Byzantine control, which had been carried into poverty by barbaric savagery (barbarica feritas)..$^{56}$

The dispute over the territory of Malaga suggests that the practice of recording the boundaries of territories was not restricted to the imperial authorities. The Baetican bishops had access to records of the land holdings of their bishoprics, including the churches over which they had jurisdiction and the boundaries of their sees. It would have been impossible for Malaga to claim back its territory or for the bishops at Seville to make a ruling if they were unable to provide evidence of the claim and thus legitimately argue for its return.

Pope Gregory I sent several letters to the defensor John, his legal representative in Spania, in 603 about the case of two deposed bishops, Stephanus (see unknown) and Januarius of Malaga. The governor Comentiolus had ejected Stephanus and Januarius from office, probably on charges of treason, and Gregory sent John to conduct an investigation that seems to have concluded that there were no legitimate grounds for the deposition. The legal dossier that Gregory sent to John (Ep. 13.49) cited a wide range of imperial laws that seem to have been designed to prove the illegality of the case against Stephanus and Januarius. ${ }^{57}$ This episode supports the proposition that the bishops of Byzantine Spain were subject to close imperial supervision, especially in relation to their connections to ecclesiastical and other authorities within Visigothic-controlled territory. Gregory's extensive citation of imperial law in support of the bishops provides further evidence for the application of imperial law in Spania. He seems to have hoped to persuade Comentiolus' successor through sustained legal argument. The government of Spania thus possessed a more effective legal and administrative infrastructure than has previously been imagined. Moreover, the bishops were sometimes victims of the vagaries of this system and on other occasions capable of attempting to turn it to their own advantage. The Discriptio Hispaniae was thus part of wide range of documentary sources, most of which only survive in a fragmentary state or via passing references, that were produced by or for the government of Spania, often, it seems, in the context of disputes over the (mis-)functioning of the bureaucracy there.

\footnotetext{
${ }^{56}$ Second Council of Seville, canon 1, Vives, ed. (1963), 163.

${ }^{57}$ Wood (forthcoming).
} 
It is clear that bishops in Byzantine and Visigothic territory played a key role in articulating an ideological barrier. Recent research has suggested that new bishoprics were probably raised on both sides of the border, while cities to which these sees belonged were subject to building programmes, including the construction of fortifications. The references that the Discriptio Hispaniae makes to metropolitans (metropolitana) may suggest an additional ecclesiastical context for the document's production.

Despite scattered references to 'metropolitans' or to the granting of rights of oversight to certain individual bishops, it is unclear when and how a system of metropolitans developed in late antique Hispania. Pablo Diaz has suggested that metropolitans did not become an established part of the church in the Iberian Peninsula until $385 .{ }^{58}$ The issue of primacy was particularly problematic within Carthaginiensis, since the province was split into Byzantine and Visigothic sectors. While the Byzantines controlled much of the coast, including the traditional provincial capital, Cartagena, the Visigoths were in possession of the vast inland rump of the province. There was thus considerable scope for dispute over ecclesiastical primacy within the province - the Byzantines controlled the most prestigious city, while the Visigoths held the majority of the bishops.

Bishop Licinianus of Cartagena communicated with Pope Gregory I in the late 580 s or early 590s. However, such letters are not necessarily indicative of his enjoying metropolitan status over the divided province of Carthaginiensis because the issues discussed may refer solely to the diocese of Cartagena. Nonetheless, this and other evidence does point towards his pre-eminence among the ecclesiastics of Spania. Particularly significant in understanding the stress that the Discriptio Hispaniae lays on metropolitans is the reaction of the church in Visigothic-controlled territory, led by the bishop of the royal capital at Toledo. It seems that, first of all, the bishops from the rump of Carthaginiensis were organised into a new ecclesiastical province called Carpetania, with its metropolitan at Toledo. Carthaginiensis was reconstituted when the Visigoths finally captured Cartagena in the mid-620s, at which point the city lost its episcopal and hence its metropolitan status. Toledo became the metropolitan see of Carthaginiensis and its bishops embarked, across the middle decades of the seventh century, on a campaign to emphasise its historical and contemporary preeminence. Saints cults were developed, hagiographies of Toledo's former bishops were written and council records may have been forged as part of this process of competition with the other illustrious bishoprics of the Iberian Peninsula. Cartagena's role in the ecclesiastical history of late antique Carthaginiensis was ignored.59

In this context, the focus of the Discriptio Hispaniae on the metropolitan status of various cities of Hispania is highly significant. The production of the Discriptio Hispaniae in the 590s, immediately following the conversion of the Visigoths from Arian to Nicene Christianity and the establishment of the province of Carpetania, events which are known to have led to a heightened anxiety on the

\footnotetext{
58 Díaz (2000), 403. On granting of a degree of oversight, see: Castillo Maldonado (2013), 233.

59 Wood (2012); see also: González Blanco (1986).
} 
part of the Byzantine authorities concerning the loyalty of the bishops of Spania - evidenced by the cases of Januarius and Stephanus discussed previously - can thus be read as a claim to ecclesiastical and political unity under the authority of Byzantine Cartagena. The stress that churchmen from Visigothic territories placed on the status, metropolitan or otherwise, of Toledo, was thus more than a general reaction against the historical significance of Cartagena, but a specific response to Byzantine claims to institutional pre-eminence for their metropolitan city in the 590s.

\section{Conclusion}

This chapter has argued that the Discriptio Hispaniae, a text contained within a ninth century manuscript from the monastery of Ripoll (ACA Ripoll 106), originates from the period in which the Byzantine Empire established a province, Spania, in the south of the Iberian Peninsula (550s-620s). The most plausible decade for the composition of the text is the 590s, a period of Byzantine investment in the province during the reign of the Emperor Maurice, although it may derive from the negotiations that took place when the Byzantines first established the province during the 550s under the Emperor Justinian. If it dates to the reign of Maurice, then it was probably written in Cartagena, the capital of the province, because it was the government and church there that had most invested in the production of such a text.

The second half of this chapter sought to develop the analysis by relating the source to a number of key contemporary contexts, reinforcing the overall argument and, in some cases, developing established interpretations of the history of Spania. While the Discriptio Hispaniae cannot possibly represent accurately the boundaries of the province in the 590s, it does suggest that the administration was interested in delineating the borders of the province, while the use of specific terminology for defensive urban sites has the potential to affect long-running debates over the extent and nature of the ByzantineVisigothic frontier. The text may also enable scholars to develop their understanding of the means by which the province was governed, in relation to diplomatic activity with the Visigoths and particularly the organisation and exploitation of territory by the Byzantines. Finally, the emphasis on the metropolitan status of Cartagena may point towards an effort on behalf of the Byzantine authorities to emphasise the historical predominance of the city in opposition to the Visigothic capital of Toledo. The Discriptio Hispaniae thus reinforces the picture that is emerging from other sources of a province that was integrated with the rest of the Byzantine western Mediterranean, experiencing similar problems and devising similar solutions to meet them. A next step would be to develop these insights and compare the systems of government and resource exploitation that were operative in Spania with those found in Italy and Africa, for instance. 


\section{Bibliography}

Abad Casal, L. and S. Gutiérrez Lloret. "Iyih. (El Tolmo de Minateda, Hellín, Albacete). Una civitas en el limes visigodo-bizantino." Antigüedad y Cristianismo 14 (1997): 591-600.

Abad Casal, L., S. Gutiérrez Lloret, B. Gamo Parras and P. Cánovas Guillén. "Una ciudad en el camino: pasado y futuro de El Tolmo de Minateda (Hellín, Albacete)." Zona Arqueológica 6 (2008): 323-336.

Andreu, R. "Nuevas aportaciones al conocimiento del Ars Gromatica Gisemundi en el manuscrito de Ripoll no 106 (Barcelona, ACA)." In Estudios de Latín Medieval Hispánico, edited by J. Martínez, O. De la Cruz and C. Ferrero, 483-492. Florence: SISMEL, 2011.

Andreu, R. Edició crítica, traducció i estudi de l'Ars Gromatica siue Geometria Gisemundi. PhD thesis. Barcelona: Universitat Autònoma de Barcelona, 2013.

Andreu, R. La Geometría de Gisemundo. Edición crítica bilingüe y estudio del ARS GROMATICA SIVE GEOMETRIA GISEMUNDI. Barcelona: Universitat Autònoma de Barcelona, 2015.

Arnaud, P. "Des documents méconnus du bornage: determinatio, depalatio, definition." In Autour des Libri coloniarum. Colonisation et colonies dans le monde romain edited by A. Gonzales and J. -Y. Guillaumin, 69-79. Paris: Presses universitaires de Franche-Comté, 2006.

Barlow, C. W. Iberian Fathers. Volume 1. Martin of Braga, Paschasius of Dumium, Leander of Seville. The Fathers of the Church. A New Translation 62. Washington: Catholic University of America Press, 1969.

Blume, F., Lachmann, K. and Rudorff, A. Gromatici veteres. Die Schriften der römischen Feldmesser. I-II. Berlin. 1848-1852.

Caballero, A., E. Gimeno, M. Ramírez and I. Sastre. "Tablero de altar de época tardoantigua hallado en Baza (Granada). ¿El primer documento epigráfico del obispo Eusebio?" Archivo Español de Arqueología 79 (2006): 287-292.

Campbell, B. The writings of the Roman Land Surveyors. Introduction, text, translation and commentary. Journal of Roman Studies Monograph 9. London: Society for the Promotion of the Roman Studies, 2000.

Campos Ruiz, J. and I. Roca Melia, eds., Santos Padres Españoles II. San Leandro, San Isidoro, San Fructuoso. Reglas monásticas de la España visigoda. Los tres libros de las «Sentencias». Biblioteca de Autores Cristianos 321. Madrid: La Editorial Catolica, 1971. 
Cardelle de Hartmann, C. ed. Victoris Tunnunensis Chronicon cum reliquiis ex Consularibus Caesaraugustanis et Iohannis Biclarensis Chronicon. Corpus Christianorum Series Latina 173A. Turnhout: Brepols, 2001.

Castillo Maldonado, P. "Conflict and Compromise: the Spanish Catholic Bishops and the Arian Kingdom of Toledo." In The Role of the Bishop in Late Antiquity: Conflict and Compromise, edited by A. Fear, J. Fernández Urbiña and M. Marcos Sanchez, 229-244. London: Bloomsbury, 2013.

Claude, D. "Die diplomatischen Beziehungen zwischen dem Westgotenreich und Ostrom (475-615)." Mitteilungen des Instituts für Österreichische Geschichtsforschung 104 (1996): 13-25

Codoñer Merino, C., ed., El "De viris illustribus" de Isidoro de Sevilla. Theses et studia philologica Salmanticensia 12 (Salamanca: Consejo Superior de Investigaciones Científicas, Instituto "Antonio de Nebrija", Colegio Trilingüe de la Universidad, 1964).

Cortes, C. Epigrafía en los confines de las ciudades romanas. Los Termini publici en Hispania, Mauretania y Numidia. Roma: L'Erma di Bretschneider. 2013.

Díaz, P. C. "El reino suevo de Hispania y su sede en Bracara." In Sedes regiae ann. 400-800, edited by J. M. Gurt and G. Ripoll, 403-423. Barcelona: Real Academia de Buenas Letras, 2000.

Feissel, D. “Trois notes sur l'empereur Maurice.” Travaux et mémoires 16 (2011): 253-272.

Fontaine, J. and P. Cazier. "Qui a chassé de Carthaginoise Sévérianus et les siens? Observations sur l'histoire familiale d'Isidore de Séville." In Estudios en Homenaje a Don Claudio Sánchez Albornoz en sus 90 años, vol. 1, 349-400. Buenos Aires: Instituto de Historia de España, 1983.

García Moreno, L. A. "Organización militar de Bizancio en la península ibérica (ss. VI-VII)." Hispania 33 (1973): 5-22.

García Moreno, L. A. Prosopografía del Reino visigodo de Toledo. Salamanca: Universidad de Salamanca, 1974.

García Moreno, L. A. Leovigildo. Unidad y diversidad de un reinado. Madrid: Real Academia de la Historia, 2008.

González Blanco, A. "El decreto de Gundemaro y la historia del siglo VII." Antigüedad y Cristianismo 3 (1986): 159-169.

González Blanco, A. "Una fuente indirecta para el conocimiento de la España bizantina: Esteban de Bizancio.” Antigüedad y Cristianismo 8 (1991): 23-50.

Hartmann, L. M. ed., Gregorii I Papae Registrum Epistolarum, II. Monumenta Germaniae Historica. Epistolae II (Berlin: Weidemann, 1899). 
Jiménez, J. L. and A. Ribera. "Valentia y su territorio desde época imperial a la antigüedad tardía: una síntesis", In Ciudad y territorio: transformaciones materiales e ideológicas entre la época clásica y el Altomedioevo, edited by D. Vaquerizo, J. A. Garriguet and A. León, 265-281. Córdoba: Universidad de Córdoba, 2014.

Kulikowski, M. Late Roman Spain and Its Cities. Baltimore: Johns Hopkins University Press, 2004.

Lindsay, W. M., ed. Isidori Hispalensis episcopi etymologiarum libri XX. Oxford: Clarendon Press, 1911.

Millàs Vallicrosa, J. Assaig d'Història de les idees físiques i matemàtiques a la Catalunya Medieval. Barcelona: Institucio Patxot, 1931.

Munk Olsen, B. L'étude des auteurs classiques latins aux IX et XII siècles. París: CNRS, 1982-1989.

Olesti, 0. and R. Andreu. "Una nueva fuente documental sobre Hispania-Spania. El Ars Gromatica Gisemundi y la Discriptio Hispaniae: actividades agrimensorias en época romana y bizantina". Gerión. Revista de Historia Antigua 34 (2016): 351-381.

Peyras, J. "Textes et pratiques gromatiques. Ecrits d'arpentage de l'Antiquité tardive. Les casae litterarum du codex Arcerianus A." Dialogues d'Histoire Ancienne 31.1 (2005): 150-171.

Prego de Lis, A. "Nueva lectura de la inscripción de "Comenciolo" del Museo Principal de Arqueología de Cartagena." In Actas del XXIV Congreso Nacional de Arqueología, Cartagena 1997, vol. 5, 95-96. Cartagena: Gobierno de la Región de Murcia, Instituto de Patrimonio Histórico, 1999

Prego de Lis, A. "La inscripción de Comitiolus del Museo Principal de Arqueología de Cartagena". In V Reunión de Arqueología Cristiana Hispánica (Cartagena 1998), 383-392. Barcelona: Institut d'Estudis Catalans, Universitat de Barcelona, 2000.

Reynolds, P. Hispania and the Roman Mediterranean, AD 100-700: Ceramics and Trade. London: Duckworth, 2010.

Riese, A. Geographi latini minores. Heilbronn: Henninger, 1878 (repr. Hildesheim: Olms, 1964).

Ripoll, G. "On the supposed frontier between the regnum Visigothorum and Byzantine Hispania." In The Transformation of frontiers from Late Antiquity to the Carolingians, edited by W. Pohl, I. Wood and H. Reimitz, 95-116. Leiden: Brill, 2000. 
Rodríguez Alonso, C., ed., Las historias de los godos, vándalos y suevos de Isidoro de Sevilla. Fuentes y Estudios de Historia Leonesa 13. León: Centro de Estudios e Investigación 'San Isidoro', 1975.

Salvador Oyonate, J. A., J. Wood and A. Caballero Cobos, "Central places, local elites and international politics: The highlands of Granada in the conflict between Visigoths and Byzantines, 550-630". Forthcoming.

Salvador Ventura, F. "Fortissimae civitates meridionales en los siglos VI y VII d.C.". In Estudios sobre las ciudades de la Bética, 447-461. Granada: Universidad de Granada, 2002.

Thulin, K. Zur Überlieferungsgeschichte des Corpus Agrimensorum. Exzerptenhandschriften und Kompendien. Göteborgs K. Vetenskaps- och Vitterhetssamhälles Handlingar, Fjärde följden, 14. Gothenburg: W. Zachrisson, 1911.

Thulin, K.. Corpus Agrimensorum Romanorum. Exzerptenhandschriften und Kompendien. Leipzig: Teubner, 1913.

Toneatto, L. "Note sulla tradizione del Corpus Agrimensorum Romanorum. I Contenuti e struttura dell'Ars Gromatica de Gisemundus (IX sec.)." Mélanges de l'école française de Rome 94 (1982): 191-313.

Toneatto, L. Codices artis mensoriae. I manoscritti degli antichi opuscoli latini d'agrimensura (V-XIX sec.), 3 vols. Spoleto. 1994-95

Vallejo Girvés, M. Hispania y Bizancio: Una relación desconocida. Madrid: Akal, 2012.

Vallejo Girvés, M. Bizancio y la España tardo Antigua. Alcalá de Henares: Universidad de Alcala de Henares, 1993.

Vallejo Girvés, M. "The Treaties between Justinian and Athanagild and the legality of the Byzantine possessions on the Iberian Peninsula." Byzantion 66 (1996): 208-218.

Vallejo Girvés, M. "Relaciones del Reino Visigodo de Tolosa con el Imperio. El Papel de las Embajadas." Arqueología, Paleontología y Etnografía Monográfico IV. Los Visigodos y su Mundo, 72-79. Madrid: Comunidad de Madrid, 1997.

Vives, J., ed. Concilios Visigóticos e Hispano-Romanos. Barcelona-Madrid: CSIC, Instituto Enrique Flórez, 1963.

Vizcaíno Sánchez, J. "Hispania y oriente durante el período de ocupación bizantina (siglos VI-VII): La documentación arqueológica." In El Oriente Greigo en la Peníinsula Ibérica: Epigrafía y Historia, edited by M. Paz de Hoz and G. Mora, 281-305. Madrid: Real Academic de la Historia, 2013. 
Vizcaíno Sánchez, J. "Avances en la definición de un patron arqueológico de la Spania bizantina." In Ianua Classicorum. Temas y formas del Mundo Clásico, edited by Jesús de la Villa Polo, P. Cañizares Ferriz, E. Falque Rey, J. Francisco González Castro, J. Siles Ruiz, vol. 3, 185-192. Madrid: Sociedad Española de Estudios Clásicos, 2015.

Wood, J. "Defending Byzantine Spain: Frontiers and Diplomacy." Early Medieval Europe 18.3 (2010): 292-319.

Wood, J. "Playing the Fame Game: Bibliography, Celebrity and Primacy in Late Antique Spain." Journal of Early Christian Studies 20.4 (2012): 613-640.

Wood, J. "The rhetoric of due process and the fear of judgement: Gregory I's letters to Byzantine Spania in 603." Forthcoming.

Zangemeister, C., ed. Pauli Orosii Historiarum aduersus Paganos libri VII. Leipzig: Teubner, 1889. 